\title{
NIH loses long-standing protection from impact of heavy budget cuts
}

Washington. The Senate budget committee has agreed a budget resolution which implies cuts of at least $\$ 1.1$ billion next year from the $\$ 11.3$ billion budget of the National Institutes of Health (NIH). The move has stunned lobbyists who had thought that biomedical research was relatively safe from the budget cutting fever sweeping through Washington.

As the Senate budget committee, chaired by Peter Domenici (Republican, New Mexico), released a proposal for cuts of $\$ 3$ billion from discretionary health programmes - of which NIH is the largest component - NIH officials estimated that it would require a cut of $\$ 1.8$ billion ( 16 per cent) in their budget.

But committee staff said that the budget assumed a reduction of only 10 per cent in NIH funding from this year's level for the 1996 financial year, which begins 1 October.

The proposal sent shock waves through the biomedical rescarch community. It had hoped to avoid the fate of scientists who depend on agencies such as the Department of Energy and the National Aeronautics and Space Administration (NASA) which are regarded as being more politically vulnerable than NIH.

The proposed cuts would be "a major catastrophe for basic research in this country," says George Mandel, chair of the National Caucus of Basic Biomedical Science Chairs, and head of the pharmacology department at George Washington University, Washington DC.

Before it is passed, the Senate budget resolution must be approved by the Senate and reconciled with the House version, crafted by budget committee chairman John Kasich (Republican, Ohio).

The House resolution proposed a $\$ 500$

\section{US campaign to target patenting on life}

Washington. A broad coalition of religious leaders from more than 80 faiths and denominations is due to launch a campaign in Washington today (18 May) against the patenting of human genes, cells and organs, as well as genetically engineered animals.

The campaign has been organized by the Foundation on Economic Trends toegther with the General Board of Church and Society of the United Methodist Church (see Nature 374, 103; 1995). It is intended to raise "critical theological concerns over the patenting of life" in churches, synagogues, mosques and temples across the United States. million ( 5 per cent) cut for NIH, and level funding for five years after that, although officials say that other pending House provisions add up to a total cut of 9 per cent in $\mathrm{NIH}$ funding next year. Neither proposal allows for inflation, which could consume a further 4 per cent from NIH's budget.

In September, appropriations committees on both sides will allocate budget funds on the basis of the limits set by the agreed budget resolution. President Clinton is due to sign - or veto - their budget by October 1 .

As far as other agencies are concerned, the Republican resolutions include a proposal from the House side to cut NASA's budget from $\$ 14.5$ billion this year to $\$ 13.7$ billion next year, and to $\$ 11.7$ billion by 2000. Over five years, $\$ 2.7$ billion would come from the space agency's Mission to Planet Earth programme and another \$1.5 billion from privatizing the space shuttle.

This proposal would maintain

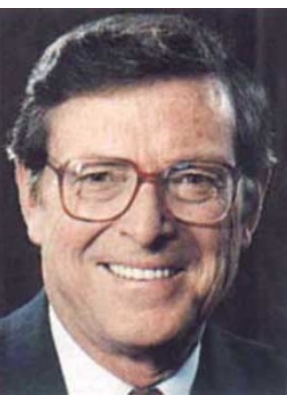
space station fund- Domenici: seeks $\mathbf{\$} 3 \mathbf{b n}$ ing at $\$ 2.1$ billion a off health spending. year. But George

Brown (Democrat, California), the senior Democrat on the House science committee, says that this would lead to unsustainable pressures on other parts of NASA.

"The Republican budget calls into question the possibility of achieving any reasonable balance among NASA programmes," says Brown. After the budget was announced, conflict between Brown and Bob Walker (Republican, Pennsylvania), chair of the science committee, over this issue led to the abandonment of their bi-partisan approach to authorization legislation for NASA.

The House resolution also proposes abolishing the Department of Energy, without saying what should happen to its constituent parts. Walker, as vice-chair of the budget committee, says he tried and failed to incorporate his plan for a new Department of Science in the resolution.

The House bill includes steep reductions in research and development on energy supply, from $\$ 3.3$ billion this year to $\$ 2.6$ billion next. But within that, it offers protection both for basic science and for the administration's Scientific Facilities Initiative.

The National Science Foundation (NSF) fares better than other science agencies under both Republican plans. The Senate proposes a cut of $\$ 100$ million from the agency's $\$ 3$ billion budget this year, but the House allows 3 per cent annual growth for NSF research programmes, except for the social sciences, a move which could lead to the complete elimination of the NSF's $\$ 120$ million social sciences programme.

Republicans in both House and Senate propose ending the Advanced Technology Programme (ATP), a scheme for supporting industrial technology which has had the misfortune to be seen as a symbol of President Clinton's science and technology policy.

The House resolution cuts funding for the United States Geological Survey (USGS) by one-fifth, and abolishes the National Biological Service (NBS). Both House and Senate would abolish the Office of Technology Assessment, which provides Congress with impartial, if long-winded, advice on science and technology issues.

Walker, whose science committee has jurisdiction over most civil science programmes except NIH, says that the budget will maintain level funding for basic research, at the expense of applied research and development. "We went after corporate welfare," he says.

Justifying the cuts on NASA's Mission to Planet Earth programme, he says that it "was structured to take care of political interests" in its orientation toward global warming. Although the programme has a scientific mission, the money used to build its satellites and data gathering systems is categorized as 'development' rather than 'research'.

But Brown scorns Walker's assertion that the budget proposal protect basic science, saying that it "threatens to destroy the investment portfolio of this nation". His staff estimate that, if adopted, it will reduce science committee programmes by 35 per cent by the year 2000 .

As for NIH, the bulk of any cuts will come from the roughly $\$ 9$ billion of its $\$ 11.3$ billion budget allocated to medical schools and other outside research centres. Sam Silverstein, president of the Federation of American Societies for Experimental Biology, and head of physiology at Columbia University, New York, brands the Senate proposal as "a disaster, which will lead to the destruction of the system" for funding biomedical research in the United States.

Silverstein and Mandei both suggest that the cut could virtually eliminate new $\mathrm{NIH}$ grants next year; Silverstein says it could mean a 1 per cent success rate for them. Alternatively, both say, the NIH might have to cut off funding for research projects already underway, in order to free up money for new work.

Colin Macilwain 